\title{
Analysis of Human Needs in Kitchen Design for People with Visual Impairment
}

\section{Analiza ljudskih potreba pri dizajniranju kuhinje za slijepe osobe}

\author{
Original scientific paper • Izvorni znanstveni rad \\ Received-prispjelo: 18. 4. 2013. \\ Accepted-prihvaćeno: 6. 2. 2014. \\ UDK: $630 * 836.1$ \\ doi:10.5552/drind.2014.1329
}

\begin{abstract}
In the modern society, about twenty percent of the population has problems with eyesight. As a result of the ageing process, it is expected that till the year 2020, the problem of visual impairment will be experienced by an increasing number of people. There is a relationship between impaired vision in old age and reduced quality of life and increased risk of dangerous situations in the kitchen. This paper is an attempt to meet and describe the desires and needs of people with visual impairment. The presented results of the survey research conducted among people with sight problems are the basis for the elaboration of design concepts for kitchen furniture. This paper describes the selected solutions of kitchen furniture designed for people with visual impairment to increase their comfort of living.
\end{abstract}

Key words: kitchen furniture, design for elderly people, visual impairment

SAŽETAK • U suvremenom društvu problem oštećenja vida obuhvaća populaciju od $20 \%$ ljudi. Kao rezultat procesa starenja, očekuje se da će do 2020. godine problem slabovidnosti iskusiti sve veći broj ljudi. Postoji veza između oštećenja vida u starijoj dobi i smanjene kvalitete života, kao i povećane opasnosti s kojom se osobe suočavaju u kuhinji. Rad je izrađen s ciljem prikupljanja želja i potreba osoba oštećeniog vida. Prezentirani rezultati ankete provedene među osobama s problemima vida služe kao osnova za dizajnerski koncept kuhinjskog namještaja. Opisana su rješenja oblikovanja kuhinjskog namještaja namijenjenoga osobama oštećena vida radi omogućivanja udobnijeg života.

Ključne riječi: kuhinjski namještaj, dizajn za starije osobe, slabovidne i slijepe osobe

\section{INTRODUCTION}

\section{UVOD}

The problem of disability can affect anybody. The constantly increasing number of the disabled is caused by several factors, including e.g. civilizationrelated diseases, road accidents, effects of environmental degradation, as well as the aging process. Assuming that almost everybody suffers from some dysfunction at a certain time in their lives, it is advisable to consider all disabilities and by addressing the needs - to create the conditions in which the disabled may also properly and fully function.

The importance and weight of this problem is indicated by the fact that, as reported by Balcerzak-Paradowska (2002), over 500 million people worldwide are suffering from different forms of disability. Visual impairment and blindness affect over 285 million indi-

\footnotetext{
${ }^{1}$ Authors are associate professor, associate professor and M.Sc. Eng. at Department of Furniture Design, Faculty of Wood Technology, Poznan University of Life Sciences, Poland.

${ }^{1}$ Autori su izvanredni profesor, izvanredni profesor i diplomant Odjela za dizajn namještaja, Fakultet drvne tehnologije, Sveučilište bioloških znanosti, Poznan, Poljska.
} 
viduals worldwide (Pascolini and Mariotti, 2012). According to the data of the Main Statistical Office (Ciecielag et al., 2006) the number of individuals with visual impairment in Poland is over 1.7 million, making visual impairment the third most common cause of disability in Poland (29.5 \%). It needs to be stressed here that this form of disability affects most frequently $(36.5 \%)$ the elderly (over 60 years of age) (GUS, 2006). Also Pascolini and Mariotti (2012) reported that $82 \%$ of all blind individuals are over 50 years old. It is of particular importance, since it is estimated that by the year 2050 every fifth individual will be at least 60 years old (United Nations, 2007). Similarly as in other European countries, also in Poland the mean life span increased from 40 years in 1900 to approx. 80 in 2000 (Lewandowski, 2000), and consequently the number of people suffering from different forms of disability is also increasing (Freedman and Martin, 1998; Hrovatin et al., 2012). Literature data report that in the year 1988 every tenth inhabitant of Poland was classified as disabled (Kowal, 2002). The number of individuals with some impairment in 1988 reached approx. 3.7 million, while in early 1993 it was over 4.5 million, accounting for approx. $11.6 \%$ of the total population, whereas in 2004 it was already over 6.2 million (GUS, 2006).

The increasing number of the disabled imposes the obligation on furniture designers to search for solutions that would at the same time combine elegance, comfort and meet the basic safety requirements. Such solutions are characteristic of more complex design methods based on ergonomics. The interdisciplinary character of this field makes it possible to create furni- ture products fully adapted to the user's needs, both physically and emotionally (Świątek, 2001).

Modern furniture designed for the disabled is primarily focused on individuals with limited motion capacity. Design products are usually not aimed at meeting the needs of individuals with visual impairment.

As a consequence of aging of the population in developed countries, the problem of visual impairment will affect an increasing number of individuals. It is essential to undertake studies on the identification of needs of this group of users, particularly as it has been proven that there is a strong dependence between visual impairment at an older age and a lower standard of living and greater probability of accidents (Evans and Rowlands, 2004). Also Acimis et al. (2009) highlight the higher risk of dangerous situations occurring in older age.

Thus the aim of this study was to collect information concerning both preferences and problems faced by the elderly or middle-aged individuals with visual impairment when working in the kitchen. An additional practical objective was to propose examples of ready design solutions for kitchen furniture for individuals aged $65+$ with visual impairment.

\section{MATERIAL AND METHODS}

2. MATERIJALI I METODE

By using questionnaires and interviews, data were collected concerning the needs, habits and problems faced by the blind or people with low vision when using the kitchen,. The assumed population size was 100 individuals suffering from different forms of

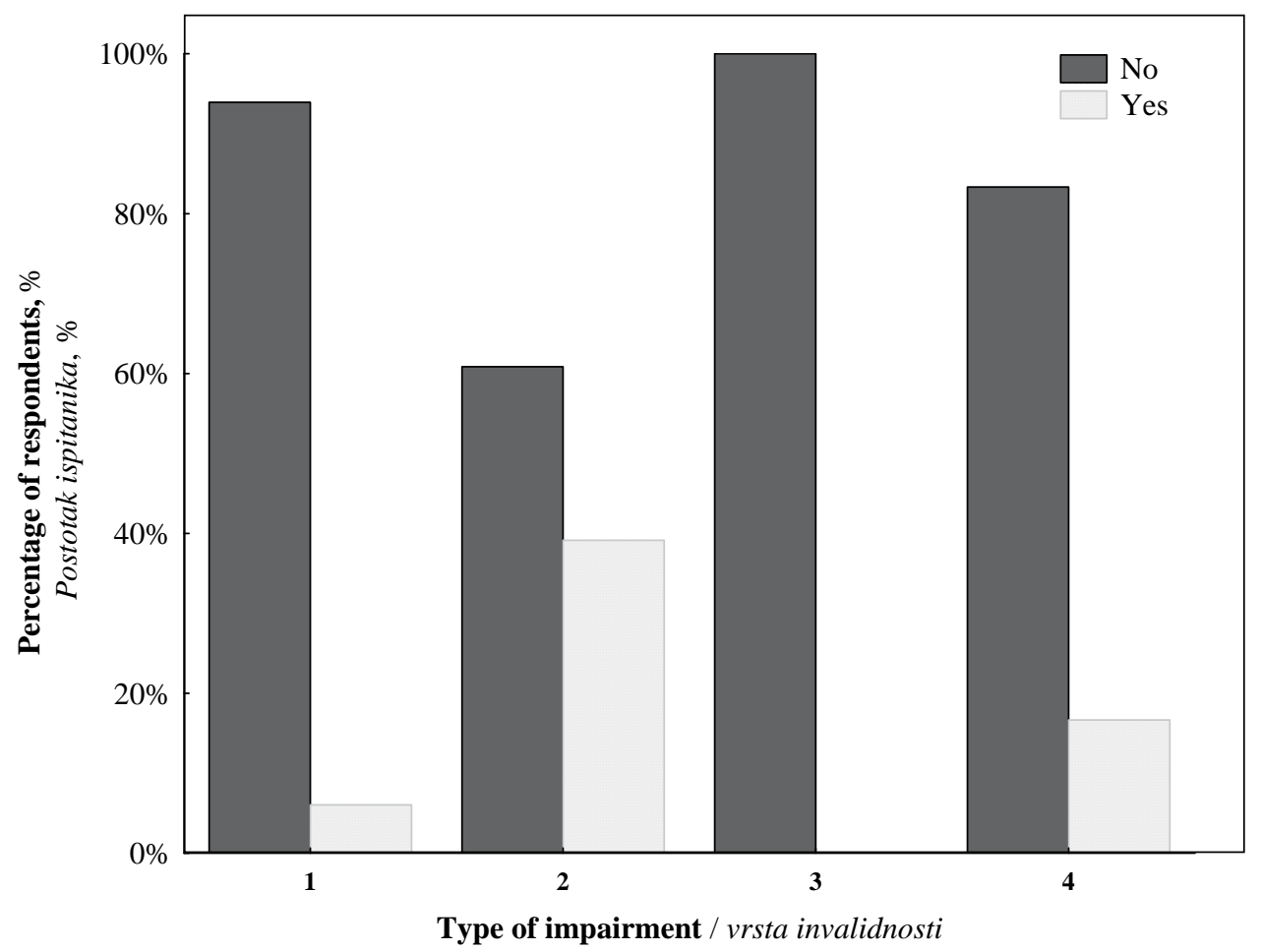

Figure 1 The structure of furniture adaptation depending on the type of disability of respondents (VI - Visual Impairment) - Blind, 2 - partly sighted, 3 - VI and wheelchair, 4 - VI and crutches etc.

Slika 1. Struktura prilagodbe namještaja vrsti invalidnosti ispitanika (VI - oštećenja vida)

- slijepe osobe, 2 - osobe djelomično oštećenog vida, 3 - slabovidne osobe u kolicima, 4 - slabovidne osobe sa štakama 


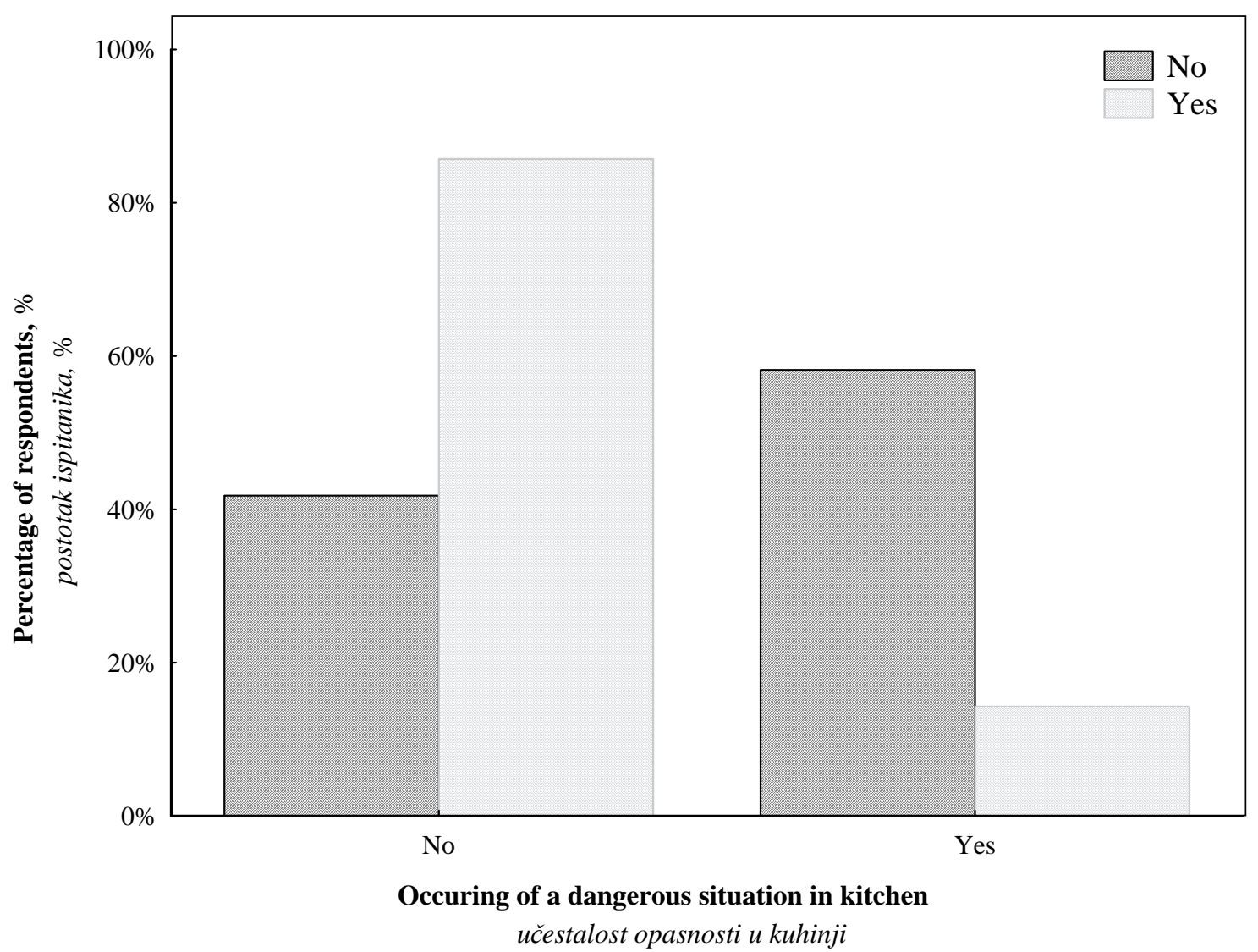

Figure 2 The relationship between the adaptation of kitchen furniture to user disability and dangerous situations occurring in the kitchen

Slika 2. Odnos između prilagodbe kuhinjskog namještaja invalidnosti korisnika i pojave opasnosti u kuhinji

visual impairment. The questionnaire consisted of closed, open and semi-open questions. The subject covered problems concerning the use of the kitchen by individuals with visual impairment, basic information on the respondents participating in the study, identification of dangerous situations when performing individual activities connected with meal preparation, evaluation of kitchen furniture in their possession as well as information on the needs and preferred changes in kitchen furnishings.

Collected data were coded and subjected to comprehensive statistical analysis. Results of the investigations constituted the basis for the development and proposals of new solutions for kitchen furniture, which could potentially enhance the comfort of living for the analyzed group of individuals. They were presented using the Autodesk Inventor ${ }^{\circledR}$ program.

\section{RESULTS AND DISCUSSION} 3. REZULTAT I RASPRAVA

Taking into consideration the percentage of returned questionnaires, their completeness and the number of direct interviews, it was decided to conduct further analysis based on data coming from 88 respondents. The results of the conducted investigations show considerable need to provide kitchen furniture designed for individuals with visual impairment. This stems from the fact that as many as $76 \%$ people in the ana- lyzed group of respondents do not have kitchen furniture adapted to their needs connected with their dysfunction. Figure 1 presents the structure of furniture adaptation to user needs depending on the type of disability of respondents.

A relationship is identified between the adaptation of kitchen furniture to users' disability and dangerous situations occurring in the kitchen (Figure 2).

For the analyzed variables, the independence Pearson test $\chi^{2}$ was conducted. The hypothesis 0 was verified: $H_{0}$ : variable $X$ (furniture is adapted to disabled person needs) and variable $Y$ (occurring of dangerous situation) are independent versus alternative hypothesis $H_{1}$ : variables $X$ and $Y$ are not independent. The results of the test indicate that this relationship is statistically significant at the level $p=0.00044\left(\chi^{2}=12.36\right)$, meaning that the variables are dependent.

Therefore, it should be emphasised that it is necessary to design furniture specifically for the needs of disabled people in order to minimize the probability of accidents in the kitchen. This is extremely important since dangerous situations happened in $48 \%$ of the analysed cases.

Dangerous situations resulting from the use of kitchen furniture with obstacles, which need to be overcome by a person with a visual impairment when staying in the kitchen, are shown in Figure 3. An analysis of the figure below shows that, next to burns (51\%) and cuts $(33 \%)$, some of the more frequent dangerous 


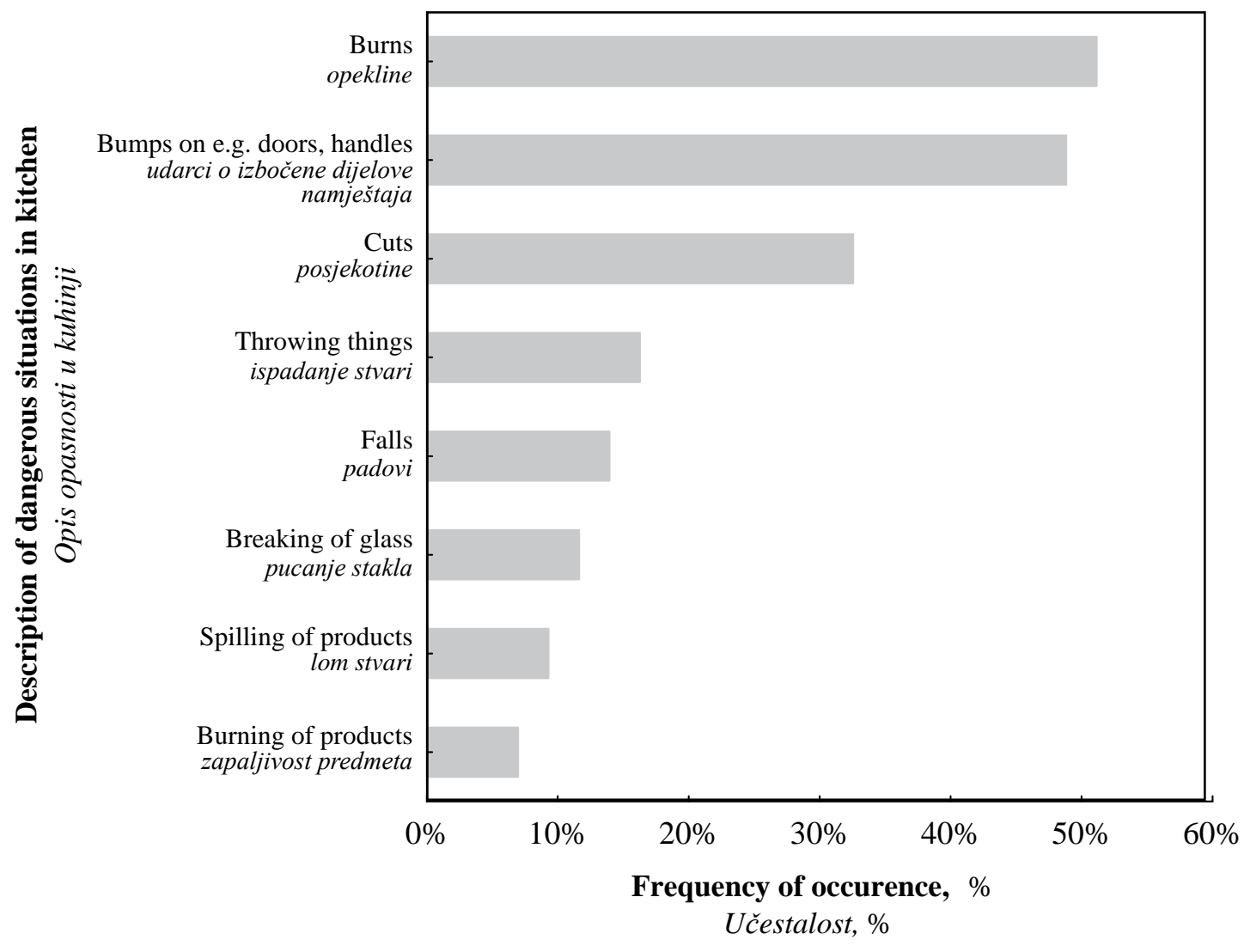

Figure 3 Dangerous situations in kitchen

Slika 3. Opasnosti u kuhinji

situations occurring in the kitchen include e.g. bumps into doors of upper cabinet, sharp edges or protruding handles $(43 \%)$. In view of the above, it would be justified to replace traditional doors with a vertical axis of rotation with sliding doors or doors opening in the vertical plane, as well as redesign furniture handles and knobs. The importance of the problem of bumping into doors or corners was also pointed out by Hrovatin et al. (2012). It was indicated in the research that as much as $72 \%$ of elderly persons faced at least once that dangerous situation.

In direct interviews a large number of respondents pointed to the problem of loss of balance when performing everyday activities. It is estimated that the elderly people and individuals with low vision fall twice as often as people with normal vision (Evans and Rowlands, 2004). The problem of balance disturbances of the elderly was also indicated by Kabsch (2000), who stressed that mortality caused by fall accidents increases drastically after 70 years of age (Kabsch, 2003; Web-based Injury Statistics..., 2004). Moreover, the results of studies conducted by the Department of Furniture Design, Poznan University of Life Sciences, show that among 136 individuals aged over 51, falls account for $38 \%$ of all dangerous situations in the kitchen. According to Stevens (2005) $30 \%$ of users over 65 experience a fall in their kitchen each year.

Based on the analysis of data presented in Figure 3 , safer solutions can be designed taking into consid- eration the needs of people with visual impairment. Thies is important since, for example, Nevitt et al. (1989) pointed out that environmental factors do play a part in about half of all home falls. Proposals as how to avoid dangerous situations in the kitchen and at the same time the basic design criteria are given in Figure 4. Special attention was focused on modifications of the existing range of furniture, resulting in greater rounding of worktops and element of subassemblies ( $29 \%$ ). Respondents pointed to the necessity of replacing traditional doors with a vertical axis of rotation with sliding doors in order to completely eliminate the risk of a bump (9\%) as well as replacing standard handles with recessed handles (7\%). The need for arranging the kitchen with furniture without handles and equipped with sliding doors was also highlighted by Hrovatin et al. (2012). The respondents would like to have induction cook tops in their kitchens; however, instead of sensory control they should have manual control (e.g. knobs) (20\%), since they are easier to operate according to respondents.

The analysis was based on data collected from respondents concerning their individual expectations for the optimal aesthetic and design solutions in kitchen furniture. Respondents declared that the furniture of their dreams should first of all be functional (24\%) and equipped with furniture hardware preventing bumps $(14 \%)$. A lot of attention was also paid to the dimensions of furniture adapted to user needs and use of ma- 


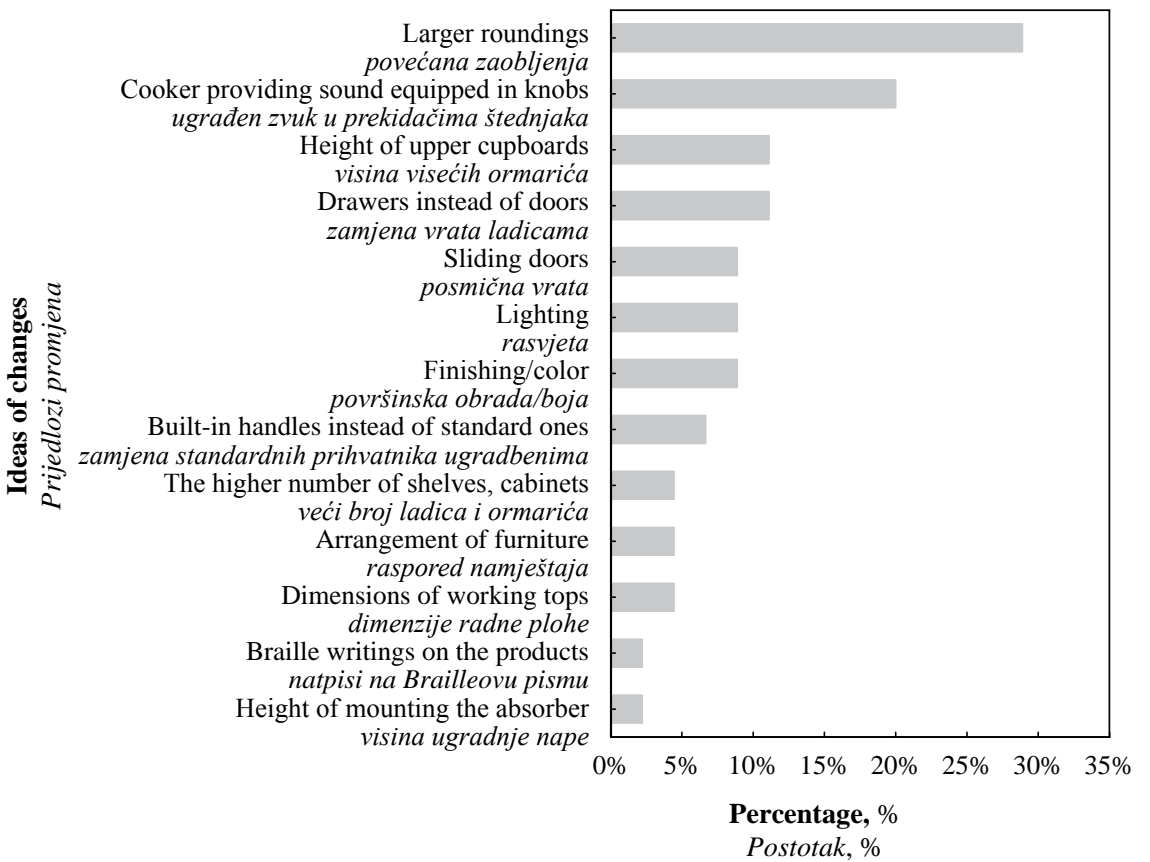

Figure 4 Modifications to be made in kitchen furniture according to respondents Slika 4. Preinake koje bi ispitanici napravili na svome kuhinjskom namještaju

terials resistant to dirt and scratches. Further to the above, functional and safe furniture, fully adapted to the needs of the future user, should be made.

\subsection{Selected solutions of kitchen furniture designed for people aged $65+$ with visual impairment}

3.1. Odabrana rješenja dizajna kuhinjskog namještaja prilagođenoga osobama oštećenog vida starijim od 65 godina

On the basis of questionnaire surveys and direct interviews, a set of guidelines was developed for the design of kitchen furniture for individuals $65+$ with visual impairment. This constituted the basis for the development of the design solutions presented below.

Two groups of hanging cabinets were proposed, with a width of $600 \mathrm{~mm}$ and $1000 \mathrm{~mm}$ (Figure 5), consisting of a non-standard solid frame, with sides at the angle of $85^{\circ}$, providing adequate lighting for the worktop, additionally to light coming from the ceiling. This is crucial, since the results of Taha and Sulaiman (2010) indicate that kitchen brightness level was lower than required by the elderly, which could affect their task performance. Moreover, according to Hrovatin et al. (2012) the amount of inadequately lit kitchens among seniors is $32 \%$ in Slovenia and $25 \%$ in Italy (Colombo et al., 1998). In the modern concept of kitchen furniture, the fronts are additionally equipped with handle strips. The long handle, placed almost along the entire width of the front, is an improvement for the blind and individuals with low vision as this enables them to quickly find, identify and open a cabinet. The front design is supplemented with a space identifier, containing the full name of objects found inside the cabinet in Braille (Figure 5, Figure 8). Furthermore, inside the cabinet, lighting is fitted with a movement detector, as suggested by many respondents.

As mentioned above, approx. $49 \%$ of respondents declared that bumping into the furniture front is one of the most frequent dangerous situations in the kitchen. It was decided to eliminate this danger by mounting, in the frame, the fittings elevating the front in vertical position (Figure 6).

Concerning the worktop standing cabinets, it was proposed to provide finishing characterised by a special structure and contrasting colour, which might be

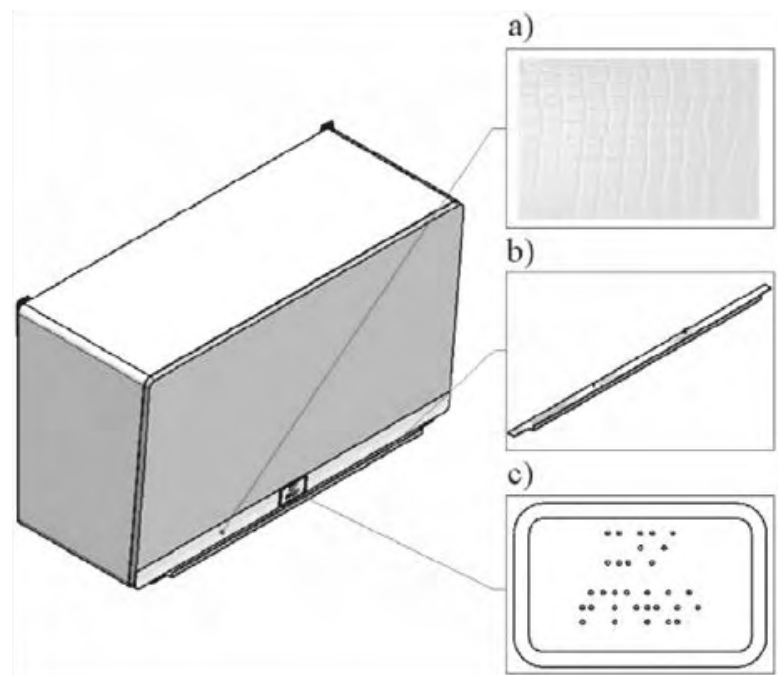

Figure 5 A hanging cabinet with improvements: a) covering, b) handle, c) the Braille space identifier Slika 5. Viseći ormarić s poboljšanjima: a) pokrov, b) prihvatnik, c) oznaka na Brailleovu pismu 


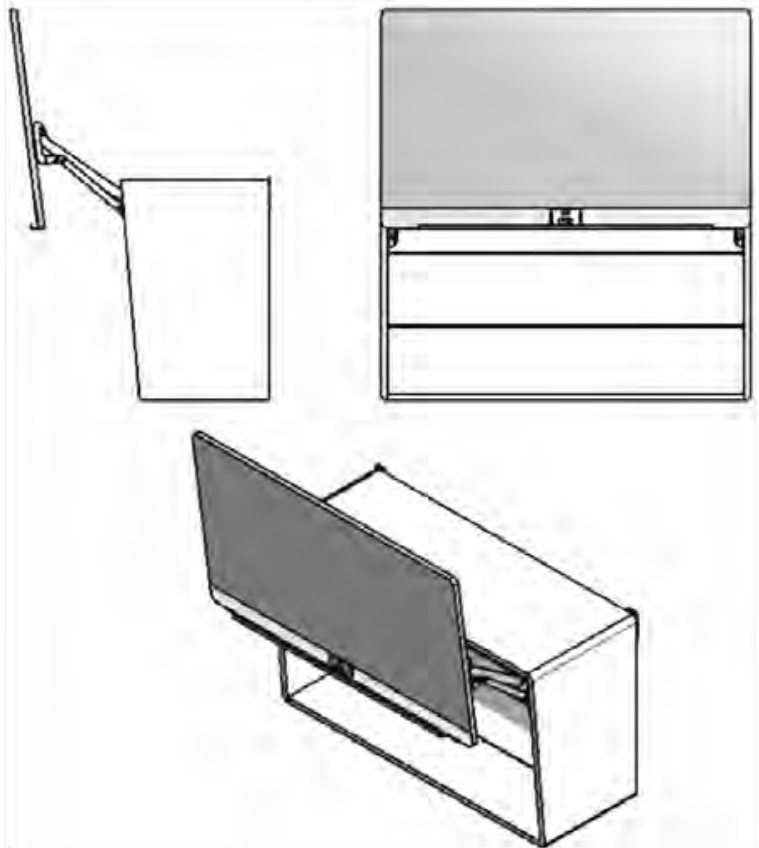

Figure 6 The method to open a hanging cabinet Slika 6. Način otvaranja visećeg ormarića helpful in the identification of the board margin and minimise the number of dangerous situations. Kowalski (2008) pointed to the fact that the contrast and colour are important aspects in the design of interiors adapted to the needs of individuals with visual impairments. Following the recommendations of respondents, the designed cabinets were equipped with drawers, from which standard, commonly used handles were removed and replaced with handles integrated with the front, made along their entire width (Figure 7). Similarly as in case of hanging cabinets, the Braille space identification system was applied on the front of every drawer. The base was removed from the front plane of the cabinet at a foot's length. This is to provide easy movement around the kitchen and prevent collisions between the user and furniture. Fronts of bottom drawers are composed of two elements, of which one is placed at an appropriate angle to the floor. The function of such a placement of bottom drawer fronts is to prevent legs hitting the front of the drawer when moving along the edge of the furniture to the next work position. a)

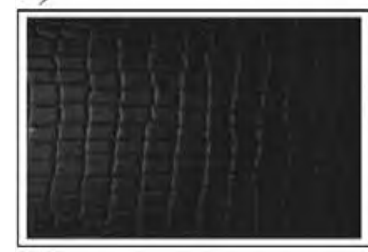

b)

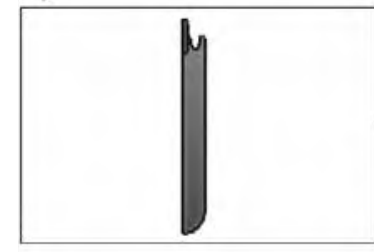

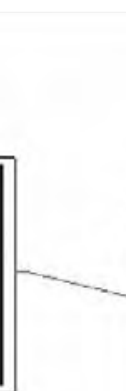

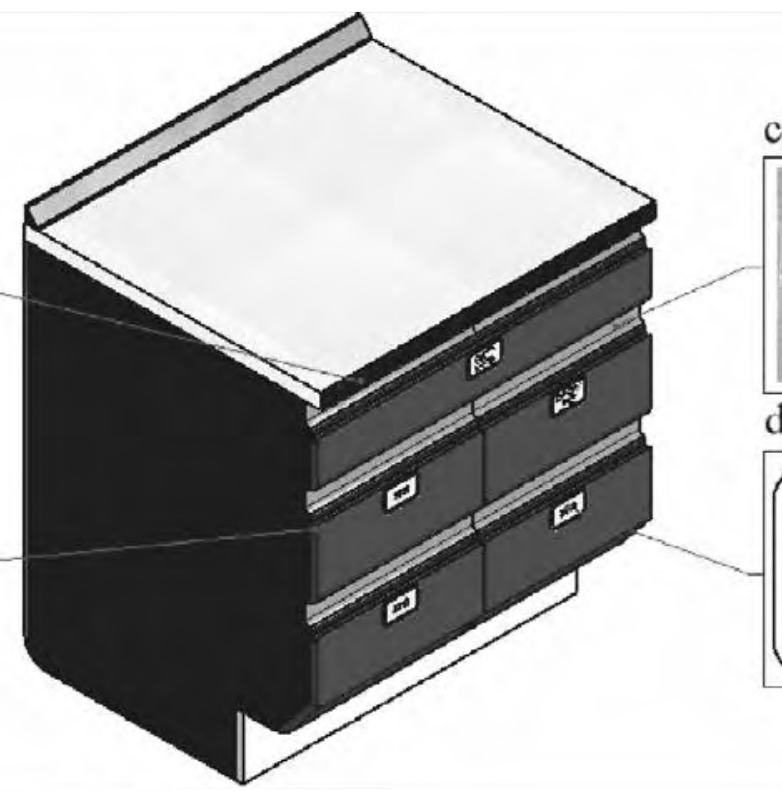

c)

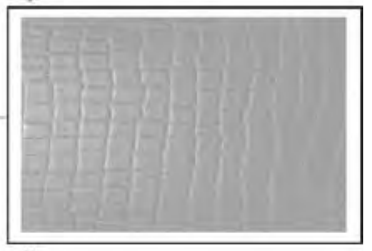

d)

$\therefore \because \because$

Figure 7 A worktop standing cabinet with improvements: a) finishing in black with a characteristic structure, b) handle, c) finishing in a light colour with a characteristic structure, d) the Braille space identifier

Slika 7. Preinake donjeg ormarića s radnom pločom: a) površina je crna i reljefna , b) upušteni prihvatnik, c) površina svijetle boje i karakteristične strukture, d) identifikator sadržaja ormarića na Brailleovu pismu 


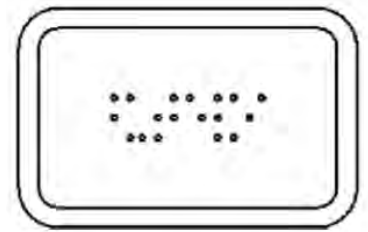

Bottles

boce

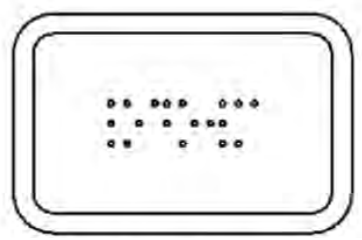

Fridge

hladnjak

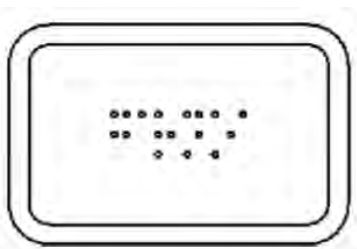

Pots

lonci

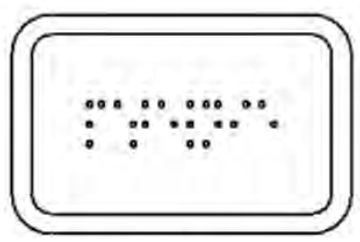

Frying pans

tave

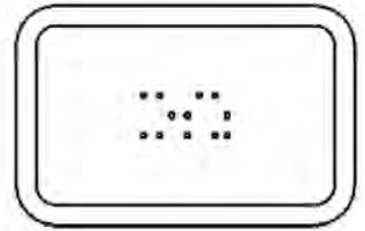

Wastebasket

kanta za otpatke

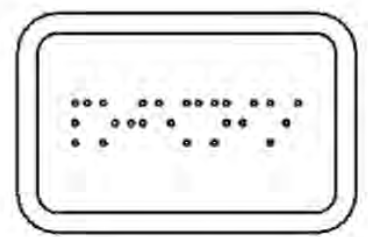

Containers

spremnici (posude)

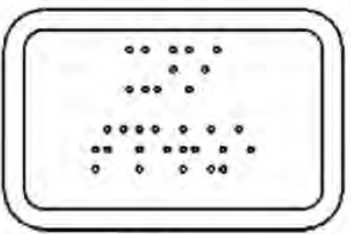

Mugs Plates

šalice $i$ tanjuri

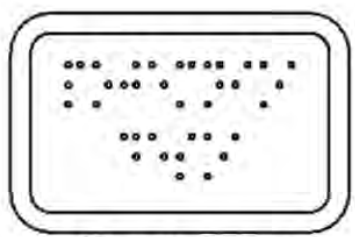

Containers Trenchers

komposter

Figure 8 Space identifiers with examples of names of objects in Braille

Slika 8. Identifikator sadržaja ormarića ispisan Brailleovim pismom

In order to limit all types of cuts, indicated by the respondents as frequent dangerous situations in the kitchen (Figure 3), it was decided to place all kitchen cutting tools in special holders in drawers. The same was done with all other kinds of cutting tools. An example solution is presented in Figure 9.

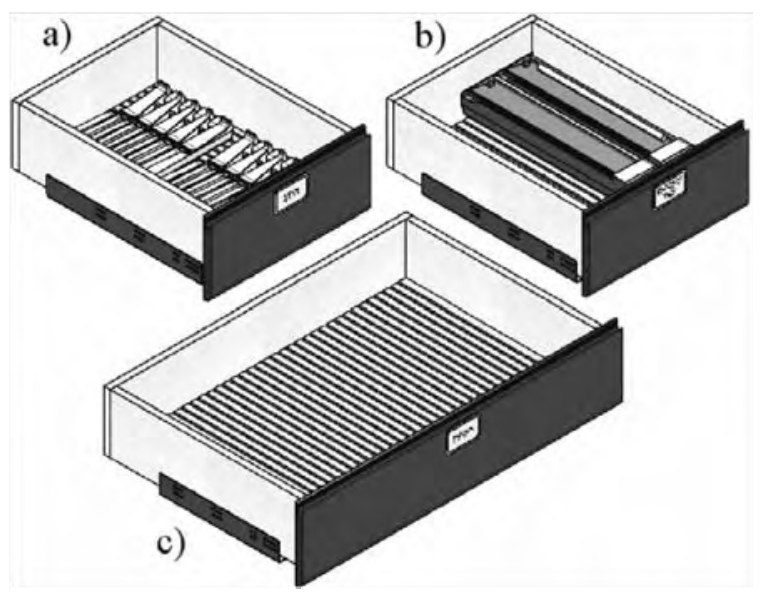

Figure 9 Middle drawers with fittings: a) a single drawer with knife holders, b) a single drawer with a foil cutter, c) a single drawer with anti-slipping mat

Slika 9. Unutrašnjost ladice s opremom: a) ladica s ležištima noževa, b) ladica s rezačem folije, c) ladica s protukliznom podlogom

Drawers with high fronts and selected types of upper drawers may be a combined system (cargo cabinets) (Figure 10), increasing the functionality of kitchen furniture.

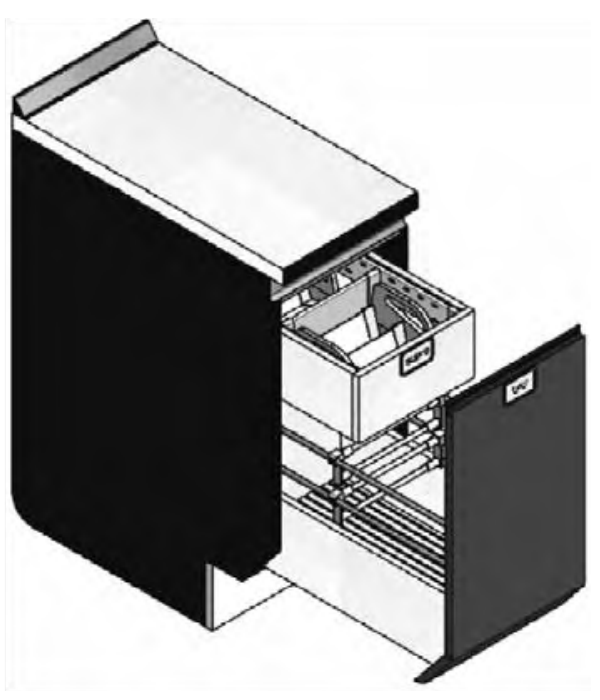

Figure 10 A Cargo standing cabinet Slika 10. Donji ormarić tipa cargo

\section{CONCLUSIONS}

4. ZAKLJUČAK

As a result of questionnaires and direct interviews, important information was gathered to facilitate designing furniture for elderly people with visual impairment. The results can be used as guidelines for designing ergonomic kitchen concepts fully adapted to the user needs.

Further to the above, the following solutions are recommended: 
1. To mount the fittings for elevating the front in vertical position or for sliding doors in the frame of upper cupboards in order to eliminate bumping into open doors.

2. To fit the cabinets with handles integrated (builtin) with the front in order to avoid bumping into protruding furniture handles.

3. When designing furniture for people with visual impairment, to use veneers (coverings) with contrast colour and special structure easy to feel and recognize by touching. It is also recommended to introduce Braille identifiers on the furniture fronts describing the cabinet content.

4. To place all cutting tools in safe drawer holders in order to limit cuts.

5. To equip the kitchen with full extension cargo cabinets in order to increase the functionality of furniture. This solution not only allows easier access to the products stored but also well-lighted cabinets.

\section{Acknowledgements - Zahvala}

This research is a part of the project: StarDust of the Baltic Sea Region Programme 2007 - 2013: The Strategic Project in Trans-national Commercial Activities in Research \& Innovation, Clusters and in SMENetworks.

This work was partly financed by the European Union (European Regional Development Fund and European Neighbourhood and Partnership Instrument).
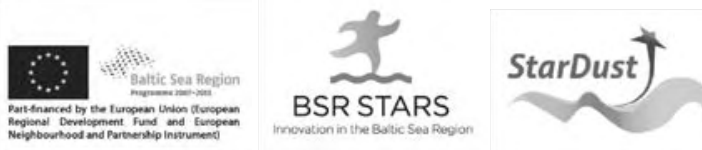

\section{REFERENCES}

\section{LITERATURA}

1. Acimis, N. M.; Mas, N.; Yazici, A. C.; Gocmen, L.; Isik, T.; Mas, R.M., 2009: Accidents of the elderly living in Kocaeli Region (Turkey). Archives of Gerontology and Geriatrics, 49: 220-223. http://dx.doi.org/10.1016/j.archger.2008.08.015

2. Balcerzak-Paradowska, B., 2002: Sytuacja osób niepełnosprawnych w Polsce. Raport Instytutu Pracy i Praw Socjalnych. Warszawa.

3. Colombo, M.; Vitali, S.; Molla, G.; Gioia P.; Milani, M., 1998: The home environment modification program in the care of demented elderly: Some examples. Archives of Gerontology and Geriatrics, 26 (1): 83-90. http://dx. doi.org/10.1016/S0167-4943(98)80015-0

4. Evans, B. J. W.; Rowlands, G., 2004: Correctable visual impairment in older people: a major unmet need. Ophthalmic and Physiological Optics, 24 (3): 161-180. http:// dx.doi.org/10.1111/j.1475-1313.2004.00197.x

5. Freedman, V. A.; Martin L. G., 1998: Understanding trends in functional limitations among older Americans. American Journal of Public Health, 88 (10): 1457-1462. http://dx.doi.org/10.2105/AJPH.88.10.1457

6. Ciecieląg, P.; Lednicki, B.; Moskalewicz, J.; Piekarzewska, M.: Sierosławski, J.; Waligórska, M.; Zajenkowska-
Kozłowska, A., 2006: Stan zdrowia ludności Polski w 2004 r. Informacje i opracowania statystyczne. Warszawa www.stat.gov.pl/cps/rde/xbcr/gus/stan_zdrowia_2004.pdf

7. Hrovatin, J.; Širok, K.; Jevšnik, S.; Oblak, L.; Berginc J., 2012: Adaptability of Kitchen Furniture for Elderly People in Terms of Safety. Drvna industrija, 63(2): 113-120. http://dx.doi.org/10.5552/drind.2012.1128

8. Kabsch, A., 2000: Niepełnosprawność jako wynik procesów starzenia. Ergonomia, 23: 57-73.

9. Kabsch, A., 2003: Potrzeby rehabilitacji w przewidywalnej przyszłości. Ergonomia Niepełnosprawnym w Przyszłości. Konferencja Naukowo-Techniczna MKEN 2003, Politechnika Łódzka: 10-20.

10. Kowal, E., 2002: Ekonomiczno - społeczne aspekty ergonomii. Wydawnictwo Naukowe PWN. Warszawa Poznań

11. Kowalski, K., 2008: Mieszkanie dostępne dla osób z dysfunkcjami wzroku, Wydawnictwo Stowarzyszenie Przyjaciół Integracji.

12. Lewandowski, J., 2000: Ergonomia niepełnosprawnym - środowisko pracy. Wydawnictwo Politechniki Łódzkiej.

13. Nevitt, M.C.; Cumming, S.R.; Kidd, S.; Black, D., 1989: Risk factors for recurrent nonsyncopal falls: a prospective study. Journal of the American Medical Association, 261 (18): 2663-2668. http://dx.doi.org/10.1001/ jama.1989.03420180087036

14. United Nations, 2007: World Population Ageing Report. Department of Economic and Social Affairs Population Division. http://www.un.org/en/development/desa/population/publications/pdf/ageing/WorldPopulationAgeingReport2007.pdf

15. Pascolini, D.; Mariotti, S. P., 2012: Global Estimates of Visual Impairment: 2010. British Journal Ophthalmology, 96 (5):614-618. http://dx.doi.org/10.1136/bjophthalmol-2011-300539.

16. Stevens, J. A., 2005: Falls Among Older Adults - Risk Factors and Prevention Strategies. Journal of Safety Research, 36: 409-411. http://dx.doi.org/10.1016/j. jsr.2005.08.001

17. Świątek, J., 2001: Kryteria ergonomiczne w procesie projektowo - konstrukcyjnym sprzętu i pomocy dla osób niepełnosprawnych. Centralny Ośrodek Badawczo-Rozwojowy Maszyn Włókienniczych POLMATEX-CENARO:1-4.

18. Taha, S.; Sulaiman, R., 2010: Perceived Kitchen Environment among Malaysian Elderly. American Journal of Engineering and Applied Sciences, 3(2): 270-276. http://dx.doi.org/10.3844/ajeassp.2010.270.276

19. *** 2004: Web-based Injury Statistics Query and Reporting System (WISQARS - interactive, online database). 2004, Centers for Disease Control and Prevention [CDC] http://www.cdc.gov/injury/wisqars/index.html (21.01.2014)

\section{Corresponding address:}

Assoc. Prof. BEATA FABISIAK, Ph.D.

Department of Furniture Design

Faculty of Wood Technology

Poznan University of Life Sciences

Wojska Polskiego Street 38/42

60-637 Poznan, POLAND

e-mail: beata.fabisiak@up.poznan.pl 